\title{
Evaluation of $\mathrm{CD}^{+} \mathrm{CD25}^{+/-} \mathrm{CD}^{+}{ }^{+} \mathrm{T}$ Cell Populations in Peripheral Blood of Patients Following Kidney Transplantation and During Acute Allograft Rejection
}

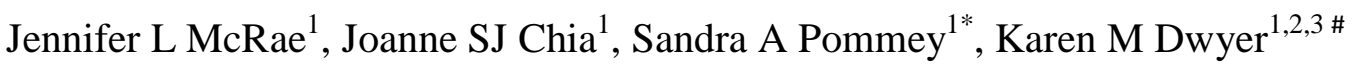

${ }^{1}$ Immunology Research Centre, ${ }^{2}$ Department of Nephrology, St. Vincent's Health, Melbourne, Australia and ${ }^{3}$ Department of Medicine, University of Melbourne, Australia.

${ }^{\#}$ Current address: School of Medicine, Faculty of Health, Deakin University, Geelong, Australia

*Current address: Centre de Recherche du Centre Hospitalier de l'Université de Montréal, 900

St-Denis Street, Montréal, Canada

Running title: CD39+ T cells in kidney transplant recipients

\section{Corresponding author:}

Professor Karen Dwyer

School of Medicine, Faculty of Health

Locked Bag 20000

Deakin University, Geelong, Victoria, 3220

Australia

Ph: +61352271421

Fax: +61 52272956

This is the author manuscript accepted for publication and has undergone full peer review but has not been through the copyediting, typesetting, pagination and proofreading process, which may lead to differences between this version and the Version of Record. Please cite this article as doi: $10.1111 /$ nep.12894

This article is protected by copyright. All rights reserved. 


\begin{abstract}
Aim: Regulatory T cells (Treg) are important in mediating immune tolerance and outcomes of allotransplantation. $\mathrm{CD} 4^{+} \mathrm{CD} 25^{+} \mathrm{CD} 39^{+}$co-expression identifies memory Treg; $\mathrm{CD} 4^{+} \mathrm{CD} 25^{-}$ $\mathrm{CD} 39^{+}$memory $\mathrm{T}$ effectors. We sought to determine $\mathrm{CD} 4^{+} \mathrm{CD} 25^{+/-} \mathrm{CD} 39^{+}$expression from the peripheral blood of patients with end stage renal failure, following transplantation and during episodes of acute cellular rejection.
\end{abstract}

Methods: $\mathrm{CD}^{+} \mathrm{T}$ cells were isolated from peripheral blood leucocytes and analysed for CD25 and CD39 expression by flow cytometry. Treg suppressive function was measured by suppression of autologous effector T-cell proliferation by Treg in co-culture.

Results: $\mathrm{CD} 4{ }^{+} \mathrm{CD} 25^{+/-} \mathrm{CD} 39^{+} \mathrm{T}$ cell subsets were tracked longitudinally in the peripheral blood of seventeen patients following renal transplantation. Patients with acute $\mathrm{T}$ cell mediated rejection diagnosed on biopsy had reduced $\mathrm{CD} 4^{+} \mathrm{CD} 25^{+} \mathrm{CD} 39^{+}$mTreg $(p<0.05)$ and $\mathrm{CD}^{+} \mathrm{CD} 25^{-} \mathrm{CD} 39^{+}$mTeff $(p<0.01)$ cells compared to non-rejecting patients. $\mathrm{CD} 4^{+} \mathrm{CD} 25^{+} \mathrm{CD} 39^{+}$mTreg $(p<0.05)$ and $\mathrm{CD} 4^{+} \mathrm{CD} 25^{-} \mathrm{CD} 39^{+}$mTeff $(p=0.057)$ were reduced in long term transplant patients (> 1 year) compared with controls. Interestingly, remaining $\mathrm{CD} 4^{+} \mathrm{CD} 25^{+} \mathrm{CD} 39^{+}$mTreg in the stable transplant patients displayed more potent suppressive capacity compared with controls $(83.2 \% \pm 3.1 \%$ vs. $45.7 \% \pm 8.0 \%$, nTeff:Treg ratio 8:1, $p<0.01)$.

This article is protected by copyright. All rights reserved. 
Conclusion: $\mathrm{CD}^{+} \mathrm{CD} 25^{+} \mathrm{CD} 39^{+}$mTreg and $\mathrm{CD} 4^{+} \mathrm{CD} 25^{-} \mathrm{CD} 39^{+}$mTeff in peripheral blood can be tracked in renal transplant patients. Acute cellular rejection was accompanied by reduced mTreg and mTeff. Determining changes in these $\mathrm{T}$ cell subsets may help to identify patients with, or at high risk of, renal allograft rejection.

KEYWORDS: Treg, CD39, renal transplantation, acute cellular rejection, kidney

Abbeviations:

ESRF - end stage renal failure

$\mathrm{CMR}$ - cell mediated rejection

KTR - kidney transplant recipient

Treg - regulatory T cells

Teff - effector T cell

mTreg - memory Treg

mTeff - memory T effector cells

nTeff - naïve T effector cells

CD39 - ectonucleoside triphosphate diphosphohydrolase 1, E-NTPDase1

CD73 - ecto-5' 'nucleotidase, ecto5'NTase

This article is protected by copyright. All rights reserved. 


\section{INTRODUCTION}

Regulatory $\mathrm{T}$ cells (Treg) are central in mediating immune homeostasis. This is particularly relevant in transplantation where the balance between Treg and the pathogenic alloreactive $\mathrm{T}$ effector cells (Teff) they suppress is vital for preservation of graft function and the induction and maintenance of tolerance.

Treg are defined by the expression of various markers however no-one marker has total specificity. Treg have traditionally been defined by $\mathrm{CD} 4{ }^{+} \mathrm{CD} 25^{+} \mathrm{FoxP} 3^{+}$expression, however recent data in mice and humans shows FoxP3 is also expressed by pathogenic cells with Th17 potential $(1,2)$.

CD39 (ectonucleoside triphosphate diphosphohydrolase 1, E-NTPDase1) is an integral vascular and immune ectonucleotidase playing critical roles in haemostasis and the immune response. The expression of CD39 by Treg is well established (3-5) and is restricted to a subset of T regulatory memory cells (6) that are capable of suppressing IL-17 production (7). We have previously shown that CD39 in combination with CD4 and CD25 identifies four distinct $T$ cell populations in the peripheral blood of mice and humans $(3,5)$. Defined as $\mathrm{CD}^{+} \mathrm{CD} 25^{+} \mathrm{CD} 9^{+}$(activated/memory Treg, mTreg); $\mathrm{CD} 4^{+} \mathrm{CD} 25^{+} \mathrm{CD} 39^{-}$(pro-T helper subset, Th); $\mathrm{CD}^{+} \mathrm{CD} 25^{-} \mathrm{CD} 39^{+}$(memory $\mathrm{T}$ effector cell, mTeff) and $\mathrm{CD} 4{ }^{+} \mathrm{CD} 25^{-} \mathrm{CD} 39^{-} \mathrm{T}$ cells (naïve T effector cell, nTeff), these populations are dynamic and can be tracked in states of inflammation such as renal transplant rejection (5). The extensive role of CD39 in conjunction with CD73 (ecto-5'-nucleotidase, ecto5'NTase) in regulation of the purinergic system and its resultant effect on inflammation and immunity is well established (reviewed in 
(8)). Conversion of the pro-inflammatory molecule ATP, via the CD39/CD73 pathway, to adenosine promotes an anti-inflammatory environment. Defects in Treg number and/or function are associated with the emergence of autoimmune disease (9), transplant rejection (10) and inflammation (11). Importantly, the level of expression and activity of CD39 on mTreg cells directly influences their immunosuppressive capacity in many disease states (5-7, 12-14) and increased CD39 expression on mTreg has been linked to operational tolerance in renal transplant patients (15).

In this study we tracked the $\mathrm{CD} 4{ }^{+} \mathrm{CD} 25^{+/-} \mathrm{CD} 39^{+} \mathrm{T}$ cell subsets in patients with end stage renal failure (ESRF) awaiting transplantation and in the first 3 months post-transplant and correlated them with episodes of acute cell mediated rejection (CMR). Further, analysis of T cell proliferation and Treg suppressive function in stable renal transplant recipients was assessed.

\section{METHODS}

\section{End stage renal failure and kidney transplant recipients}

Peripheral blood samples were obtained prospectively from kidney transplant recipients (KTR) with ESRF recruited from the Nephrology Unit at St. Vincent's Hospital, Melbourne, Australia. $10 \mathrm{ml}$ of blood was drawn for analysis in those that received a renal transplant during the early post-operative period (day 1-6), at the time of indicated biopsy (biopsy for an unexpected rise in serum creatinine) and at their 3 month protocol biopsy. Written 
informed consent was obtained from all patients and healthy controls and this study was approved by the St. Vincent's Hospital (Melbourne) Human Ethics Committee.

\section{Human peripheral blood mononuclear cell (PBMC) preparation and Treg isolation}

PBMC were obtained by Ficoll gradient and $\mathrm{CD}^{+} \mathrm{T}$ cells isolated using MACS microbeads (Miltenyi Biotec Australia, Macquarie Park, NSW, Australia). For phenotypic analysis CD4 ${ }^{+}$ T cells were stained with anti-human CD4-PE-Cy7, CD39-APC and CD25-APC-Cy7 (BD Biosciences Australia, North Ryde, NSW, Australia \& eBioscience, San Diego, CA, USA). Samples were analysed on a FACSCanto (BD Biosciences) and expression assessed using FlowJo software (Tree Star, Ashland, OR, USA).

\section{mTreg Suppression and nTeff Proliferation Assays}

Peripheral blood samples for the suppression and proliferation analysis were sourced from controls and KTR (stable >1 year) who required venesection but were otherwise well: the KTR for polycythaemia; the controls for iron overload. PBMC were obtained by Ficoll gradient and $\mathrm{CD}^{+}{ }^{+} \mathrm{T}$ cells purified using the $\mathrm{CD} 4^{+} \mathrm{T}$ cell Isolation Kit II and AUTOMACS (Miltenyi Biotec Australia, Macquarie Park, NSW, Australia). $\mathrm{CD}^{+}$cells were stained as described above and $\mathrm{CD} 4^{+} \mathrm{CD} 25^{+} \mathrm{CD} 39^{+}$mTreg and $\mathrm{CD} 4^{+} \mathrm{CD} 25^{-} \mathrm{CD} 39^{-}$nTeff populations were isolated following flow cytometry cell sorting (FACS Aria, BD Biosciences, San Jose, CA). nTeff cells were stained with CFSE using the CellTrace ${ }^{\mathrm{TM}}$ CFSE Cell Proliferation Kit (Molecular Probes ${ }^{\mathrm{TM}}$, Thermo Scientific, Melbourne, Australia). nTeff were activated using

Treg Suppression Inspector, human (Miltenyi Biotec). A total of $5 \times 10^{4}$ nTeff cells/well 
cultured in a 1:2 cell:bead ratio in a final volume of $220 \mu \mathrm{L}$ of complete medium ((RPMI1640 containing Glutamax, 1mM Pen-Strep, 1mM Na-Pyruvate (Gibco ${ }^{\mathrm{TM}}$, Thermo Scientific, Melbourne, Victoria, Australia), 10\% Human AB serum (Invitogen ${ }^{\mathrm{TM}}$, Thermo Scientific) and 50mM 2-mercaptoethanol (Sigma-Aldrich, Castle Hill, NSW, Australia)). To assess suppressive activity, mTreg were co-cultured at nTeff:Treg ratios of 1:1 to 8:1 for 4 days. Following culture, wells were washed and cells were incubated with mouse anti-human CD4APC Ab (BD Biosciences) at 1:100 dilution for 30 minutes at room temperature. Cells were washed and resuspended in PBS $+2 \%$ BSA. 7AAD (BD Biosciences) was added to exclude dead cells prior to FACS analysis. $\mathrm{CD}^{+}$cells were gated and nTeff proliferation assessed using FlowJo Version 7.6 Proliferation Platform (Tree Star), on a FACSCanto (BD Biosciences).

\section{Statistical Analysis}

Two-tailed Student's $t$-test and one-way ANOVA were used for comparison of flow cytometry data with $p<0.05$ considered significant. Results are represented as mean \pm standard error of the mean (SEM). Statistical analysis was performed using statistical software GraphPad Prism version 5.01 (GraphPad Software Inc., La Jolla, CA, USA).

\section{RESULTS}

\section{Patient demographics and clinical characteristics of kidney transplant recipients.}


Seventeen acute transplant recipients were recruited. Transplant specific data is detailed in Table 1. Patient 1-11 did not experience rejection, although three KTR underwent a clinically indicated biopsy due to an unexplained rise in creatinine, whereas patient 12-17 had an episode of acute cellular rejection diagnosed on biopsy (Tables 1\&2). All 17 patients received the same immunosuppressive regimen of induction with basiliximab followed by maintenance therapy with a calcineurin inhibitor, mycophenolate mofetil and prednisolone.

Details pertaining to four long-term ( $>1$ year) renal transplant recipients are presented in Table 3. Maintenance therapy for these patients included mycophenolate mofetil and prednisolone. Patient 18 and 20 were on cyclosporine, patient 19, and 21 on tacrolimus. These patients had polycythemia requiring regular venesection. In addition blood was analysed from four non-transplant, non-immunosuppressed individuals undergoing venesection for iron overload to act as a comparator.

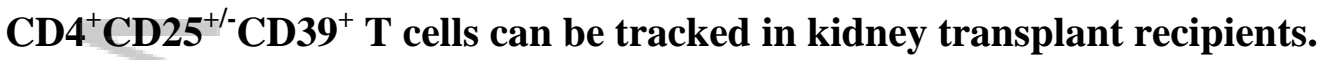

The $\mathrm{CD} 4{ }^{+} \mathrm{CD} 25^{+/-} \mathrm{CD} 39^{+} \mathrm{T}$ cell subsets in peripheral blood were isolated as shown in Figure 1. $\mathrm{CD} 4^{+} \mathrm{CD} 25^{+} \mathrm{CD} 39^{+}$mTreg and $\mathrm{CD} 4^{+} \mathrm{CD} 25^{-} \mathrm{CD} 39^{+}$mTeff populations were assessed longitudinally in eleven patients (patient 1-11) both prior to and following transplantation (Figure 2). None of these patients experienced allograft rejection although three patients (patient 1, 3 and 5) did undergo a clinically indicated biopsy due to an unexplained rise in creatinine. In these patients no cause for the rise in serum creatinine was evident on biopsy and it was attributed to acute calcineurin toxicity. Some expected inter-patient variation in population numbers was noted over time however, as previously reported (5) 
immunosuppression did not have a significant impact on $\mathrm{CD}^{+} \mathrm{CD} 25^{+/-} \mathrm{CD} 39^{+} \mathrm{T}$ cell populations over time.

$\mathrm{CD4}^{+} \mathrm{CD}^{+} \mathrm{CD39}^{+}$mTreg and $\mathrm{CD4}^{+} \mathrm{CD}^{+} \mathrm{CD}^{-}{ }^{+}$mTeff are lowered in patients with $\mathrm{T}$ cell mediated rejection in the peri-transplant period.

$\mathrm{CD} 4{ }^{+} \mathrm{CD} 25^{+/-} \mathrm{CD} 39^{+} \mathrm{T}$ cell populations were compared in those patients with a documented episode of acute cell mediated rejection (patient 12-17) and with those without rejection (patient 1-11). Patients with acute $\mathrm{T}$ cell mediated rejection had fewer $\mathrm{CD} 4^{+} \mathrm{CD} 25^{+} \mathrm{CD} 39^{+}$ mTreg (ESRF: $1.4 \pm 0.6$ vs. $3.2 \pm 0.9, \mathbf{T} \mathbf{x}<7$ days: $1.1 \pm 0.5$ vs. $2.4 \pm 0.4$, indicated biopsy: $0.8 \pm 0.2$ vs. $1.9 \pm 0.4 ; p<0.05$ and protocol biopsy: $0.8 \pm 0.3$ vs. $1.9 \pm 0.3)$ and $C D 4^{+} \mathrm{CD} 25^{-}$ $\mathrm{CD} 9^{+}$mTeff (ESRF: $1.3 \pm 0.5$ vs. $2.9 \pm 0.9$, Tx<7 days: $1.0 \pm 0.2$ vs. $3.5 \pm 1.0$, indicated biopsy: $1.0 \pm 0.3$ vs $3.0 \pm 0.1 ; p<0.01$ and protocol biopsy: $0.9 \pm 0.4$ vs $1.8 \pm 0.5)$ at all time points compared with patients without rejection, this difference reaching significance at the time of indicated biopsy (Figure 3).

$\mathrm{CD4}^{+} \mathrm{CD25}^{+/-} \mathrm{CD}^{+} \mathrm{T}$ cell populations are reduced in immunosuppressed kidney transplant recipients.

$\mathrm{CD} 4{ }^{+} \mathrm{CD} 25^{+/-} \mathrm{CD} 39^{+}$ARIA sorted samples were collected for the purpose of $\mathrm{T}$ cell suppression assays. The percent of $\mathrm{CD} 25^{+-} \mathrm{CD} 39^{+/-} \mathrm{T}$ cells within the $\mathrm{CD} 4^{+}$population of controls and long-term (>1 year) KTR (patient 18-21) were recorded based on gating of individual populations. A reduction of mTreg $(1.9 \pm 0.4$ vs. $6.9 \pm 0.7, p<0.05)$ and mTeff 
$(1.4 \pm 0.4$ vs. $4.6 \pm 1.1, p=0.057)$ populations in renal transplant patients compared with controls was observed (Figure 4A and 4B respectively).

\section{$\mathrm{CD4}^{+} \mathrm{CD}^{+} \mathrm{CD39}^{+}$mTreg in stable kidney transplant recipients display more potent suppressive capacity.}

nTeff and mTreg from controls and KTR (patient 18-21) were assessed for their proliferative and suppressive capacity respectively. Figure 5A shows the proliferative capacity of $\mathrm{CD} 4^{+} \mathrm{CD} 25^{-} \mathrm{CD} 39^{-}$nTeff. Although some variation within the immunosuppressed KTR group was observed, overall there was no significant difference in proliferative capacity of the nTeff population between KTR as a group and controls. However, $\mathrm{CD} 4^{+} \mathrm{CD} 25^{+} \mathrm{CD} 39^{+} \mathrm{mTreg}$ in KTR beyond one year post-transplant displayed more potent suppressive capacity compared with controls (nTeff:Treg ratio 8:1, 83.2\% $\pm 3.1 \%$ vs. $45.7 \% \pm 8.0 \%, p<0.01$ ) (Figure 5B).

\section{DISCUSSION}

The differential expression of CD25 and CD39 identifies four distinct human $\mathrm{CD}^{+} \mathrm{T}$ cell populations and importantly, distinguishes between Treg and pathogenic populations that secrete pro-inflammatory cytokines (5). The data presented in this series of experiments supports our previous observation that these populations are dynamic and can be monitored in renal transplant patients (5). Alterations in the mTreg population have also been documented in other inflammatory conditions (16-19) highlighting their dynamic nature and 
raising questions of their stability in states of inflammation. In the renal transplant setting the possible prognostic value of assessing Treg number and/or ratio Treg;Teffector in peripheral blood and at the graft site has yielded varying results and interpretations recently reviewed in Braza et al (20). We have previously reported that in healthy controls and stable patients with ESRF or following transplantation, no significant difference in the percentage of these $\mathrm{T}$ cell subsets is observed and Treg:Tmeff populations are in a ratio of 1:1. However during episodes of acute antibody mediated rejection in KTR, this ratio was heavily skewed to the $\mathrm{CD} 4^{+} \mathrm{CD} 25^{-} \mathrm{CD} 39^{+}$mTeff population and appeared proportional to the severity of rejection histologically (5).

In this cohort, we sought to assess the $\mathrm{CD} 4^{+} \mathrm{CD} 25^{+} \mathrm{CD} 39^{+}$mTreg and $\mathrm{CD} 4^{+} \mathrm{CD} 25^{-} \mathrm{CD} 39^{+}$ mTeff populations in individual patients prior to and following transplantation including during episodes of acute cell mediated rejection. We successfully followed seventeen individual patients longitudinally, sampling at ESRF, within 7 days of transplantation, at the time of indicated biopsy and at the 3-month protocol biopsy (Figure 2). When the $\mathrm{CD} 4{ }^{+} \mathrm{CD} 25^{+/-} \mathrm{CD} 39^{+} \mathrm{T}$ cell numbers from patients with and without acute cell mediated rejection were compared, a consistent reduction was observed in both $\mathrm{CD} 4^{+} \mathrm{CD} 25^{+} \mathrm{CD} 39^{+}$ mTreg and $\mathrm{CD}^{+} \mathrm{CD} 25^{-} \mathrm{CD} 39^{+}$mTeff populations both prior to transplant, in the peritransplant period, significantly at the time of indicated biopsy and remaining reduced thereafter (Figure 3). Reduced numbers within these $\mathrm{T}$ cell subsets during this time period may indicate a predisposition to rejection due to a less regulated inflammatory environment. Indeed, increased frequency of $\mathrm{CD} 9^{+}$Treg and the level of CD39 expression on Treg has 
been associated with better suppressive capacity in a variety of autoimmune and inflammatory disorders $(6,7,21,22)$.

We also sought to assess $\mathrm{CD} 4^{+} \mathrm{CD} 25^{+} \mathrm{CD} 39^{+}$mTreg function in a cohort of stable KTR. To obtain adequate cell numbers for our assay, peripheral blood samples were obtained from controls and stable KTR who required venesection. Interestingly, where we previously reported no difference in $\mathrm{CD} 4{ }^{+} \mathrm{CD} 25^{+/-} \mathrm{CD} 39^{+} \mathrm{T}$ cell population numbers between healthy controls and stable KTR (5), in the current study we noted a decrease in both percentage of mTreg and mTeff in KTR compared to controls. The main difference between this and our previous study is that patients recruited for Treg functional assessment were polycythemic necessitating venesection. Indeed a recent series of papers (23-25) has shown that polycythemia in the setting of underlying myeloproliferative neoplasms may alter Treg number. Although variation in $\mathrm{T}$ cell number is often attributed to the effects of immunosuppression (reviewed in (26)), in this instance, the impact of polycythemia should be considered.

Although the desired effect of immunosuppression is to target pathogenic T effector cells, we have shown that in the $\mathrm{CD} 4^{+} \mathrm{CD} 25^{-} \mathrm{CD} 39^{-}$nTeff population, no difference in the proliferative capability between control and KTR was observed (Figure 5A). Interestingly, despite immunosuppression, the suppressive capacity of the $\mathrm{CD} 4^{+} \mathrm{CD} 25^{+} \mathrm{CD} 39^{+} \mathrm{mTreg}$ in stable immunosuppressed KTR is similar to that of controls at nTeff:Treg ratios of 1:1 and 2:1 (Figure 5B). Of particular note is the ability of mTreg to sustain suppression in the presence 
of greater nTeff numbers suggesting that this population is particularly potent on a per cell basis.

Braza et al have recently shown that increased proportions of $\mathrm{CD} 4^{+} \mathrm{CD} 45 \mathrm{RA} F$ FoxP $3{ }^{\text {hi }}$ mTregs are found in operationally tolerant renal transplant patients (15). Additionally, San Segundo et al also described increased numbers of $\mathrm{CD} 4{ }^{+} \mathrm{CD} 25^{+} \mathrm{CD} 127^{\text {low }} \mathrm{Foxp} 3^{+}$were associated with better graft outcomes in KTR (27). Based on our previous phenotyping data (5), we postulate that these populations are equivalent to the mTreg population we describe herein. Indeed, Braza showed that the CD4 ${ }^{+} \mathrm{CD} 45 \mathrm{RA}^{-} \mathrm{FoxP}^{\text {hi }} \mathrm{T}$ cells also expressed higher levels of CD39. Additionally, their work showed that this $\mathrm{T}$ cell subset displayed increased FoxP3 TSDR (Treg specific demethylation region), increased GITR (glucocorticoid-induced TNF-related receptor) and had greater suppressive properties in operationally tolerant recipients compared to those from patients with stable graft function (15). Notably, a recent study by Roederer $e t$ al (28) confirms that the frequency of $\mathrm{CD}^{+} \mathrm{CD} 39^{+}$Treg cells is highly heritable and specifically due to the genetic control of CD39 cell surface expression. Although we have not directly assessed the expression levels of CD39 on mTreg in this study, the increased levels of the $\mathrm{CD} 4^{+} \mathrm{CD} 25^{+} \mathrm{CD} 39^{+}$mTreg subset in our stable graft patients compared with those who experienced $\mathrm{T}$ cell mediated rejection suggests that the stable KTR may be less susceptible to CMR. These studies highlight the importance of assessing both cell frequency and cell surface CD39 expression and we propose the assessment of CD39 as a Treg marker should be considered in future KTR studies.

This article is protected by copyright. All rights reserved. 
The ability of Treg to regulate the inflammatory response has identified them as a clinical therapeutic candidate in the transplantation setting. Indeed, Treg cellular therapy for KTR is currently being assessed in clinical trials (https://clinicaltrials.gov/ct2/show/NTCT02088931; https://clinicaltrials.gov/ct2show/NCT021298810). However, contradictory to this study and that published by Braza et al (15) and San Sagundo et al (27), a recent multicentre study showed that $\mathrm{a}$ high proportion of pre-transplantation $\mathrm{CD}^{+} \mathrm{CD} 25^{\mathrm{hi}} \mathrm{CD} 62 \mathrm{~L}^{+} \mathrm{CD} 45 \mathrm{RO}^{+}$ activated Treg predicted acute rejection in renal transplantation (29). These data highlight the inherent difficulties defining Treg and the consequent challenges associated with using Treg therapeutically. The heterogeneity of this population makes development and targeting Treg to specific clinical settings increasingly complex: not only do Treg employ a range of suppressive molecular mechanisms, it is now apparent that these mechanisms vary depending on location and the condition of the microenvironment. Such changes in the local milieu have the potential to positively or negatively impact Treg function.

In this study we have demonstrated that:

- CD4, CD25 and CD39 identify mTreg, mTeff cell populations in the peripheral blood which can be tracked in renal transplant patients.

- mTreg and mTeff cell populations in peripheral blood are lower in renal transplant patients who experience an episode of CMR at all time points reaching statistical significance at the time of rejection.

This article is protected by copyright. All rights reserved. 
- mTreg in transplant patients with stable graft function display more potent suppressive capacity compared with controls.

We propose that determining changes within these $\mathrm{T}$ cell subsets, in conjunction with serum creatinine and calcineurin inhibitor levels, may help identify patients with, or at risk of, renal allograft rejection. Furthermore, the suppressive potency of the $\mathrm{CD} 4^{+} \mathrm{CD} 25^{+} \mathrm{CD} 39^{+}$mTreg population suggests these markers could be considered in Treg isolation for clinical purposes.

\section{ACKNOWLEDGEMENTS:}

The authors acknowledge the support from the following funding source: TSANZ - Amgen Research Grant Award 2009. The authors also thank staff from the Department of Nephrology (St Vincent's Hospital, Fitzroy, 3065, Victoria, Australia), for assistance with patient recruitment and sample collection.

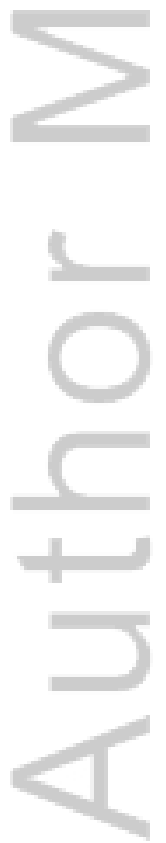

This article is protected by copyright. All rights reserved. 


\section{REFERENCES:}

1. Miyara M, Yoshioka Y, Kitoh A, Shima T, Wing K, Niwa A, et al. Functional Delineation and Differentiation Dynamics of Human CD4(+) T Cells Expressing the FoxP3 Transcription Factor. Immunity. 2009 May 20. PubMed PMID: 19464196. Epub 2009/05/26. Eng.

2. $=$ Zhou Q, Yan J, Putheti P, Wu Y, Sun X, Toxavidis V, et al. Isolated CD39 expression on CD4+ $\mathbf{T}$ cells denotes both regulatory and memory populations. Am $\mathbf{J}$ Transplant. 2009 Oct;9(10):2303-11. PubMed PMID: 19656134. Pubmed Central PMCID: 2930268.

3. Deaglio S, Dwyer KM, Gao W, Friedman D, Usheva A, Erat A, et al. Adenosine generation catalyzed by CD39 and CD73 expressed on regulatory $\mathrm{T}$ cells mediates immune suppression. J Exp Med. 2007 Jun 11;204(6):1257-65. PubMed PMID: 17502665. Pubmed Central PMCID: 2118603. Epub 2007/05/16. eng.

4. Dwyer KM, Deaglio S, Gao W, Friedman D, Strom TB, Robson SC. CD39 and control of cellular immune responses. Purinergic Signal. 2007 Mar;3(1-2):171-80. PubMed PMID: 18404431. Pubmed Central PMCID: 2096766. Epub 2008/04/12. Eng. 5. Dwyer KM, Hanidziar D, Putheti P, Hill PA, Pommey S, McRae JL, et al. Expression of CD39 by human peripheral blood CD4+ CD25+ T cells denotes a regulatory memory phenotype. Am J Transplant. 2010 Nov;10(11):2410-20. PubMed PMID: 20977632. Pubmed Central PMCID: 2966025. Epub 2010/10/28. eng.

6. Borsellino G, Kleinewietfeld M, Di Mitri D, Sternjak A, Diamantini A, Giometto R, et al. Expression of ectonucleotidase CD39 by Foxp3+ Treg cells: hydrolysis of 
extracellular ATP and immune suppression. Blood. 2007 Aug 15;110(4):1225-32. PubMed PMID: 17449799. Epub 2007/04/24. eng.

7. Fletcher JM, Lonergan R, Costelloe L, Kinsella K, Moran B, O'Farrelly C, et al. CD39+Foxp3+ regulatory $T$ Cells suppress pathogenic Th17 cells and are impaired in multiple sclerosis. J Immunol. 2009 Dec 1;183(11):7602-10. PubMed PMID: 19917691. Epub 2009/11/18. eng.

8. Antonioli L, Pacher P, Vizi ES, Hasko G. CD39 and CD73 in immunity and inflammation. Trends in molecular medicine. 2013 Jun;19(6):355-67. PubMed PMID: 23601906. Pubmed Central PMCID: 3674206.

9. Sakaguchi S, Sakaguchi N, Asano M, Itoh M, Toda M. Immunologic selftolerance maintained by activated $\mathrm{T}$ cells expressing IL-2 receptor alpha-chains (CD25). Breakdown of a single mechanism of self-tolerance causes various autoimmune diseases. J Immunol. 1995 Aug 1;155(3):1151-64. PubMed PMID: 7636184. Epub 1995/08/01. eng.

10. Waldmann H, Adams E, Fairchild P, Cobbold S. Infectious tolerance and the long-term acceptance of transplanted tissue. Immunol Rev. 2006 Aug;212:301-13. PubMed PMID: 16903922. Epub 2006/08/15. eng.

11. Wahl SM, Vazquez $\mathbf{N}$, Chen $W$. Regulatory $T$ cells and transcription factors: gatekeepers in allergic inflammation. Curr Opin Immunol. 2004 Dec;16(6):768-74. PubMed PMID: 15511671. Epub 2004/10/30. eng.

12. Gibson DJ, Elliott L, McDermott E, Tosetto M, Keegan D, Byrne K, et al. Heightened Expression of CD39 by Regulatory T Lymphocytes Is Associated with 
Therapeutic Remission in Inflammatory Bowel Disease. Inflammatory bowel diseases. 2015 Dec;21(12):2806-14. PubMed PMID: 26332314.

13. Li P, Gao Y, Cao J, Wang W, Chen Y, Zhang G, et al. CD39+ regulatory T cells attenuate allergic airway inflammation. Clinical and experimental allergy : journal of the British Society for Allergy and Clinical Immunology. 2015 Jun;45(6):1126-37. PubMed PMID: 25728362.

14. Peres RS, Liew FY, Talbot J, Carregaro V, Oliveira RD, Almeida SL, et al. Low expression of $\mathrm{CD39}$ on regulatory $\mathrm{T}$ cells as a biomarker for resistance to methotrexate therapy in rheumatoid arthritis. Proc Natl Acad Sci U S A. 2015 Feb 24;112(8):2509-14. PubMed PMID: 25675517. Pubmed Central PMCID: 4345589.

15. Braza F, Dugast E, Panov I, Paul C, Vogt K, Pallier A, et al. Central Role of CD45RA- Foxp3hi Memory Regulatory $T$ Cells in Clinical Kidney Transplantation Tolerance. J Am Soc Nephrol. 2015 Aug;26(8):1795-805. PubMed PMID: 25556168.

16. Bailey-Bucktrout SL, Martinez-Llordella M, Zhou X, Anthony B, Rosenthal W, Luche $\mathbf{H}$, et al. Self-antigen-driven activation induces instability of regulatory $\mathbf{T}$ cells during an inflammatory autoimmune response. Immunity. 2013 Nov 14;39(5):949-62. PubMed PMID: 24238343. Pubmed Central PMCID: 3912996.

17. Herrath J, Muller M, Amoudruz P, Janson P, Michaelsson J, Larsson PT, et al. The inflammatory milieu in the rheumatic joint reduces regulatory T-cell function. Eur J Immunol. 2011 Aug;41(8):2279-90. PubMed PMID: 21607944.

18. Zhou X, Bailey-Bucktrout SL, Jeker LT, Penaranda C, Martinez-Llordella M, Ashby M, et al. Instability of the transcription factor Foxp3 leads to the generation of 
pathogenic memory $T$ cells in vivo. Nat Immunol. 2009 Sep;10(9):1000-7. PubMed PMID: 19633673. Pubmed Central PMCID: 2729804.

19. Komatsu N, Okamoto K, Sawa S, Nakashima T, Oh-hora M, Kodama T, et al. Pathogenic conversion of Foxp3+ $\mathbf{T}$ cells into $\mathbf{T H 1 7}$ cells in autoimmune arthritis. Nat Med. 2014 Jan;20(1):62-8. PubMed PMID: 24362934.

20. Braza F, Durand M, Degauque N, Brouard S. Regulatory T Cells in Kidney Transplantation: New Directions? Am J Transplant. 2015 Sep;15(9):2288-300. PubMed PMID: 26234373.

21. Herrath J, Chemin K, Albrecht I, Catrina AI, Malmstrom V. Surface expression of CD39 identifies an enriched Treg-cell subset in the rheumatic joint, which does not suppress IL-17A secretion. Eur J Immunol. 2014 Oct;44(10):2979-89. PubMed PMID: 24990235.

22. Moncrieffe H, Nistala K, Kamhieh Y, Evans J, Eddaoudi A, Eaton S, et al. High expression of the ectonucleotidase CD39 on $\mathrm{T}$ cells from the inflamed site identifies two distinct populations, one regulatory and one memory $\mathbf{T}$ cell population. $\mathbf{J}$ Immunol. 2010 Jul 1;185(1):134-43. PubMed PMID: 20498355. Pubmed Central PMCID: 2890024. Epub 2010/05/26. eng.

23. Keohane C, Kordasti S, Seidl T, Perez Abellan P, Thomas N, Mufti G, et al. JAK Inhibition Reduces CD25 high CD27+ FOXp3+ T Regulatory Cells and Causes a Silencing Of T Effector Cells In Patients With Myeloproliferative Neoplasms Whilst Promoting a TH17 Phenotype. Blood. 2013;122(21). 
24. Gangemi S, Allegra A, Profita M, Saitta S, Gerace D, Bonanno A, et al. Decreased plasma levels of IL-33 could contribute to the altered function of Th2 lymphocytes in patients with polycythemia vera and essential thrombocythemia. Cancer investigation. 2013 Mar;31(3):212-3. PubMed PMID: 23402297.

25. Riley CH, Jensen MK, Brimnes MK, Hasselbalch HC, Bjerrum OW, Straten PT, et al. Increase in circulating $\operatorname{CD4}(+) \operatorname{CD25}(+) \operatorname{Foxp3(+)} T$ cells in patients with Philadelphia-negative chronic myeloproliferative neoplasms during treatment with IFN-alpha. Blood. 2011 Aug 25;118(8):2170-3. PubMed PMID: 21708889.

26. De Serres SA, Sayegh MH, Najafian N. Immunosuppressive drugs and Tregs: a critical evaluation! Clinical journal of the American Society of Nephrology : CJASN. 2009 Oct;4(10):1661-9. PubMed PMID: 19696218.

27. San Segundo D, Fernandez-Fresnedo G, Rodrigo E, Ruiz JC, Gonzalez M, Gomez-Alamillo $\mathrm{C}$, et al. High regulatory $\mathrm{T}$-cell levels at 1 year posttransplantation predict long-term graft survival among kidney transplant recipients. Transplant Proc. 2012 Nov;44(9):2538-41. PubMed PMID: 23146447.

28. Roederer M, Quaye L, Mangino M, Beddall MH, Mahnke Y, Chattopadhyay P, et al. The genetic architecture of the human immune system: a bioresource for autoimmunity and disease pathogenesis. Cell. 2015 Apr 9;161(2):387-403. PubMed PMID: 25772697. Pubmed Central PMCID: 4393780.

29. San Segundo D, Millan O, Munoz-Cacho P, Boix F, Paz-Artal E, Talayero P, et al. High proportion of pretransplantation activated regulatory $\mathbf{T}$ cells (CD4+CD25highCD62L+CD45RO+) predicts acute rejection in kidney transplantation: 
results of a multicenter study. Transplantation. 2014 Dec 15;98(11):1213-8. PubMed

PMID: 25083613.

\section{FIGURE LEGENDS}

Figure 1: Representative patient analysis and gating of peripheral blood mononuclear cells (PBMC). A maximum of 100,000 events within the lymphocyte gate were collected. (A) Forward Scatter (FSC-A) versus Side Scatter (SSC-A) dot plot of CD4 ${ }^{+}$T cells isolated from PMBC of control or renal patient with gated peripheral blood lymphocytes (PBL) identified based on size and granularity. (B) and (C) indicate doublet removal from lymphocyte population. (D) PBMC gated based on CD4 expression. (E) $\mathrm{CD}^{+}$population examined for the expression of $\mathrm{CD} 25$ and $\mathrm{CD} 39$ and proportion of $\mathrm{CD} 4{ }^{+} \mathrm{CD} 25^{+} \mathrm{CD} 39^{+} \mathrm{mTreg}$ and $\mathrm{CD} 4^{+} \mathrm{CD} 25^{-} \mathrm{CD} 39^{+}$mTeff were determined. (F) Population hierarchy of PBMC analysis. 
Figure 2: $\mathrm{CD}^{+} \mathrm{T}$ cell subpopulations sampled in eleven patients $(\mathrm{Pt})$ with end stage renal failure (ESRF), within 7 days of transplantation ( $\mathrm{Tx}<7$ days), at the time of clinically indicated biopsy and 3-month protocol biopsy. (A) $\mathrm{CD} 4^{+} \mathrm{CD} 25^{+} \mathrm{CD} 39^{+}$mTreg cells; (B) $\mathrm{CD} 4^{+} \mathrm{CD} 25^{-} \mathrm{CD} 39^{+}$mTeff cells.

Figure 3: Patients with cell mediated rejection (CMR - black bar) and those that did not reject (grey bar) prior to transplantation (ESRF), within the first seven days of transplantation ( $\mathrm{Tx}<7$ days), at the time of a clinically indicated biopsy for a rise in creatinine and at the time of protocol biopsy (A) $\mathrm{CD} 4^{+} \mathrm{CD} 25^{+} \mathrm{CD} 39^{+}$mTreg cells and (B) $\mathrm{CD} 4^{+} \mathrm{CD} 25^{-} \mathrm{CD} 39^{+}$mTeff cells.

Figure 4: $\% \mathrm{CD}^{+} \mathrm{T}$ cell subsets in controls and KTR (>1year) following ARIA sort. (A) $\mathrm{CD}^{+} \mathrm{CD} 25^{+} \mathrm{CD} 39^{+}$mTreg cells, (B) $\mathrm{CD} 4^{+} \mathrm{CD} 25^{-\mathrm{CD}} 39^{+}$mTeff cells.

Figure 5: $\mathrm{CD} 4^{+} \mathrm{CD} 25^{-} \mathrm{CD} 39^{-}$nTeff proliferative and $\mathrm{CD} 4^{+} \mathrm{CD} 25^{+} \mathrm{CD} 39^{+} \mathrm{mTreg}$ suppressive capacity in KTR (>1year) kidney transplant recipients (KTR) and controls. (A) \% proliferation of $\mathrm{CD} 4^{+} \mathrm{CD} 25^{-} \mathrm{CD} 39^{-}$nTeff cells and (B) $\mathrm{CD} 4^{+} \mathrm{CD} 25^{+} \mathrm{CD} 39^{+}$mTreg suppressive activity in stable (>1year) KTR (circle) and controls (square).

This article is protected by copyright. All rights reserved. 


\section{TABLES:}

Table 1: Demographics and clinical characteristics in KTR.

\begin{tabular}{|c|c|c|c|c|c|c|c|c|}
\hline Patient & Age & Gender & $\begin{array}{l}\text { Tx } \\
\text { type }\end{array}$ & $\begin{array}{l}\text { Primary } \\
\text { disease }\end{array}$ & DGF & $\begin{array}{l}\text { 3-month } \\
\text { Se Cr }\end{array}$ & $\begin{array}{l}\text { 3-month } \\
\text { eGFR }\end{array}$ & $\begin{array}{l}\text { HLA } \\
\text { mismatch }\end{array}$ \\
\hline Patient $1^{\#}$ & 47 & M & DD & $\begin{array}{l}\text { Solitary kidney; } \\
\text { HT }\end{array}$ & No & 237 & 26 & 3 \\
\hline Patient 2 & 56 & $\mathrm{~F}$ & DD & T2D & No & 74 & 52 & 3 \\
\hline Patient $3^{\#}$ & 66 & $\mathrm{~F}$ & DD & Reflux & No & 118 & 40 & 4 \\
\hline Patient 4 & 33 & $\mathrm{M}$ & LRT & GN & No & 107 & 60 & 2 \\
\hline Patient $5^{\sharp}$ & 34 & $\mathrm{~F}$ & DD & Alports & Yes & 200 & 25 & 2 \\
\hline Patient 6 & 49 & $\mathrm{M}$ & DD & APCKD & No & 140 & 50 & 1 \\
\hline Patient $7=$ & 53 & $\mathrm{M}$ & LRT & $\operatorname{IgA}$ & No & 101 & 67 & 0 \\
\hline Patient 8 & 54 & $\mathrm{M}$ & LURT & APCKD & No & 108 & 60 & 3 \\
\hline Patient 9 & 41 & $\mathrm{M}$ & DD & IgA & No & 140 & 49 & 1 \\
\hline Patient 10 & 48 & $\mathrm{M}$ & DD & nephrocalcinosis & No & 139 & 48 & 5 \\
\hline Patient 11 & 52 & $\mathrm{M}$ & DD & T1D & No & 74 & 70 & 4 \\
\hline Patient $12 \dagger$ & 37 & M & DD & Reflux & No & 178 & 38 & 3 \\
\hline Patient $13 \dagger$ & 38 & M & DD & $\operatorname{IgA}$ & No & 104 & 70 & 3 \\
\hline Patient $14 \dagger$ & 58 & M & DD & HT & Yes & 131 & 49 & 3 \\
\hline Patient $15 \dagger$ & 61 & $\mathrm{M}$ & DD & HT & Yes & 145 & 43 & 3 \\
\hline Patient $16 \dagger$ & 34 & $\mathrm{M}$ & LRT & FSGS & No & 130 & 55 & 2 \\
\hline Patient $17 \dagger$ & 34 & M & DD & FSGS & No & 142 & 50 & 2 \\
\hline
\end{tabular}

Tx - transplant; DD - Deceased Donor; LRT - Living related transplant; LURT - Living unrelated transplant; HT - Hypertension; T1D - type 1 diabetes; T2D - type 2 diabetes; GN - 
Glomerulnephritis; APCKD - adult polycystic kidney disease; IgA - IgA nephropathy; FSGS - Focal and segmental glomerulosclerosis; DGF - delayed graft function; $\mathrm{Se} \mathrm{Cr}$ - serum creatinine; eGFR estimated glomerular filtration rate; HLA mismatch - human leukocyte antigen mismatch.

\# Patient with no rejection at time of indicated biopsy. $†$ Patient with rejection at time of indicated biopsy.

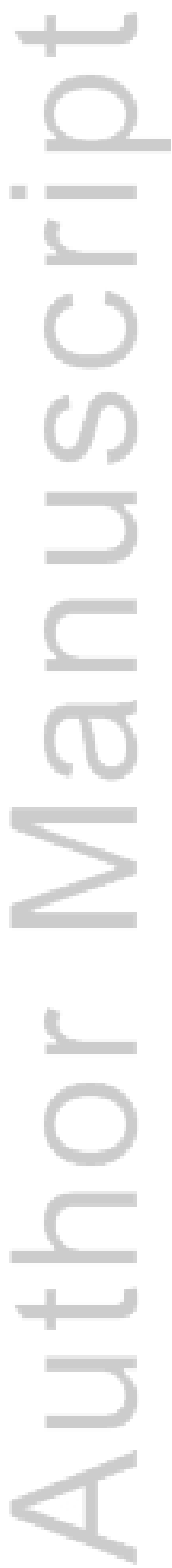

This article is protected by copyright. All rights reserved. 
Table 2: Banff staging score for KTR with rejection at time of indicated biopsy.

\begin{tabular}{|c|c|c|c|}
\hline Patient & Diagnosis & Banff acute rejection score & $\begin{array}{l}\text { Banff chronic rejection } \\
\text { score }\end{array}$ \\
\hline Patient 12 & $\begin{array}{l}\text { Borderline }(15-20 \%) \\
\text { acute T cell mediated } \\
\text { rejection. C4d negative. }\end{array}$ & $\mathrm{i} 1, \mathrm{t} 2, \mathrm{~g} 0, \mathrm{v} 0, \mathrm{ptc} 0$ & $\begin{array}{l}\text { ci0, ct0, } \operatorname{cg} 0, \operatorname{cv} 0, \text { ah0, } \\
\mathrm{mm} 0\end{array}$ \\
\hline $\begin{array}{c}=\sqrt{n} \\
\text { Patient } 1\end{array}$ & $\begin{array}{l}\text { Acute T cell mediated } \\
\text { rejection. Grade IB. C4d } \\
\text { negative. }\end{array}$ & $\mathrm{i} 2, \mathrm{t} 3, \mathrm{~g} 0, \mathrm{v} 0, \mathrm{ptc} 0$ & $\begin{array}{l}\text { ci1-2, ct1-2, cg0, cv0, ah0, } \\
\text { mm0 }\end{array}$ \\
\hline Patient & $\begin{array}{l}\text { Borderline (10\%) acute } \mathrm{T} \\
\text { cell mediated rejection. } \\
\text { C4d negative. }\end{array}$ & $\mathrm{i} 1, \mathrm{t} 1-2, \mathrm{~g} 0, \mathrm{v} 0, \mathrm{ptc} 0$ & $\begin{array}{l}\text { ci0, ct0, } \operatorname{cg} 0, \operatorname{cv} 0, \text { ah0, } \\
\text { mm0 }\end{array}$ \\
\hline Patient & $\begin{array}{l}\text { Borderline }(15-20 \%) \\
\text { acute } \mathrm{T} \text { cell mediated } \\
\text { rejection. C4d negative. }\end{array}$ & $\mathrm{i} 1, \mathrm{t} 1, \mathrm{~g} 0, \mathrm{v} 0, \mathrm{ptc} 0$ & $\begin{array}{l}\mathrm{ci}<1, \mathrm{ct}<1, \operatorname{cg} 0, \mathrm{cv} 0, \text { ah1, } \\
\mathrm{mm} 0\end{array}$ \\
\hline Patient 16 & $\begin{array}{l}\text { Suspicious for } \\
\text { suspicious/borderline } \\
\text { acute interstitial rejection } \\
(10 \%) . \text { C4d negative. }\end{array}$ & $\mathrm{i}<1, \mathrm{t}<1, \mathrm{~g} 0, \mathrm{v} 0, \mathrm{ptc} 0$ & $\begin{array}{l}\mathrm{ci}<1, \mathrm{ct}<1, \mathrm{cg} 0, \mathrm{~mm} 0, \mathrm{cv} 0, \\
\text { ah0 }\end{array}$ \\
\hline Patient 17 & $\begin{array}{l}\text { T-cell mediated } \\
\text { interstitial. C4d negative. }\end{array}$ & $\mathrm{i} 2, \mathrm{t} 1-2, \mathrm{~g} 0, \mathrm{v} 0, \mathrm{ptc} 0$ & $\begin{array}{l}\text { ci1-2, ct1-2, cg0, mm0, } \\
\text { cv1, ah1 }\end{array}$ \\
\hline
\end{tabular}

KTR - kidney transplant recipient 
Table 3: Demographics and clinical characteristics in KTR (>1 year).

\begin{tabular}{|c|c|c|c|c|c|c|c|c|c|}
\hline Patient & Age & Gender & $\begin{array}{l}\text { Tx } \\
\text { type }\end{array}$ & $\begin{array}{l}\text { Date } \\
\text { of } T x\end{array}$ & $\mathrm{Se} \mathrm{Cr}$ & eGFR & uACR & $\begin{array}{l}\text { HLA } \\
\text { Mismatch }\end{array}$ & Drug \\
\hline Patient 18 & 48 & M & LRT & 1998 & 155 & 42 & 6.6 & 2 & $\begin{array}{l}\text { CyA } \\
353 \\
\mu \mathrm{g} / \mathrm{L}\end{array}$ \\
\hline Patient 19 & 68 & $\mathrm{~F}$ & DD & 2010 & 99 & 49 & 7.4 & 4 & $\begin{array}{l}\text { Tac } \\
3.5 \mu \mathrm{g} / \mathrm{L}\end{array}$ \\
\hline Patient 20 & 40 & M & LURT & 2012 & 168 & 43 & 12.2 & 4 & $\begin{array}{l}\text { CyA } \\
726 \\
\mu \mathrm{g} / \mathrm{L}\end{array}$ \\
\hline Patient 21 & 49 & M & DD & 2012 & 151 & 46 & 3.6 & 2 & $\begin{array}{l}\text { Tac } \\
5.4 \mu \mathrm{g} / \mathrm{L}\end{array}$ \\
\hline
\end{tabular}

KTR - kidney transplant recipient; Tx - transplant, $\mathrm{Se} \mathrm{Cr}$ - serum creatinine; eGFR - estimated glomerular filtration rate; uACR - urinary albumin creatinine ratio; HLA - human leukocyte antigen; CyA - 2 hour post dose Cyclosporine level; Tac - pre-dose Tacrolimus level 

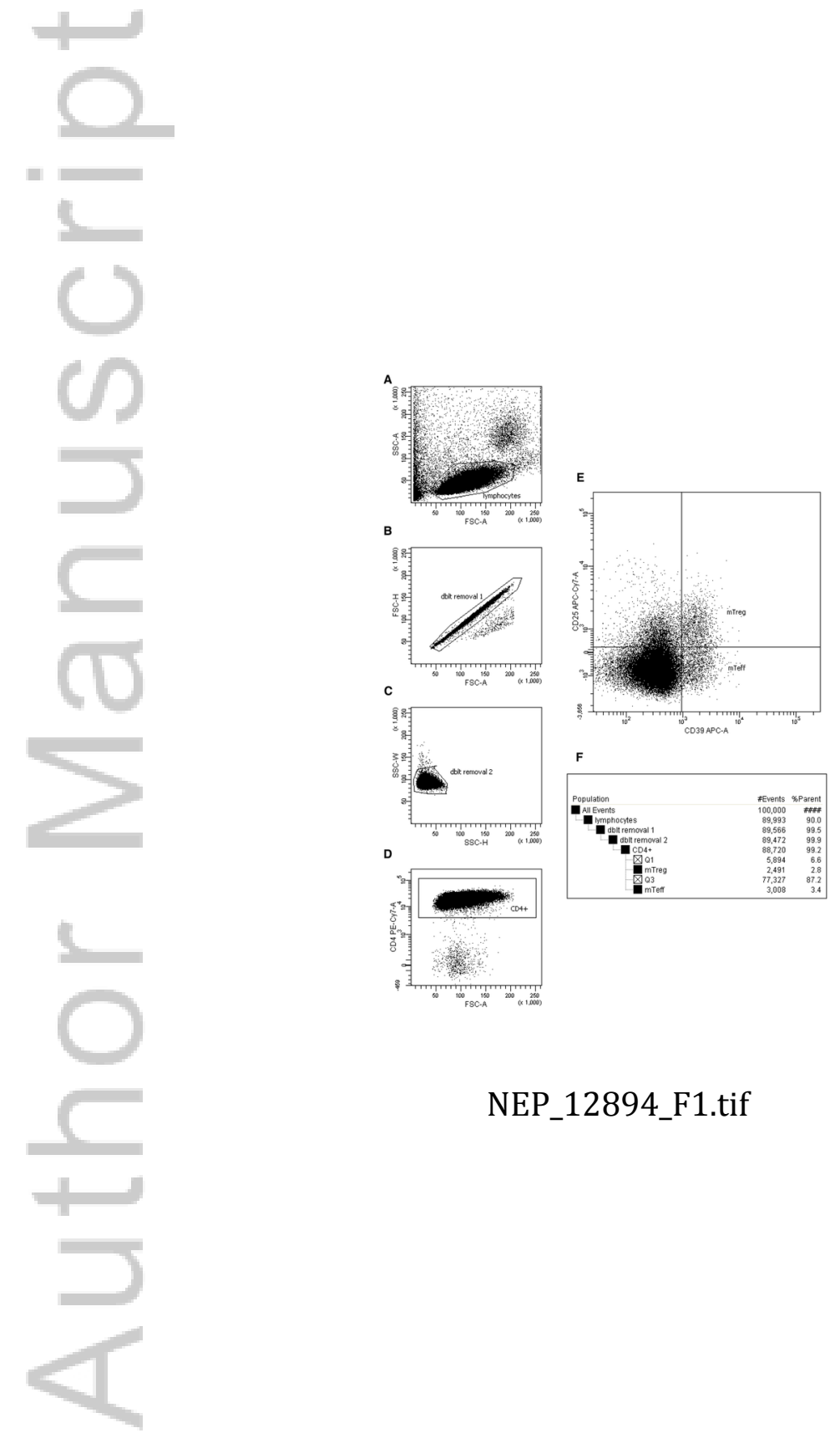

NEP_12894_F1.tif

This article is protected by copyright. All rights reserved. 


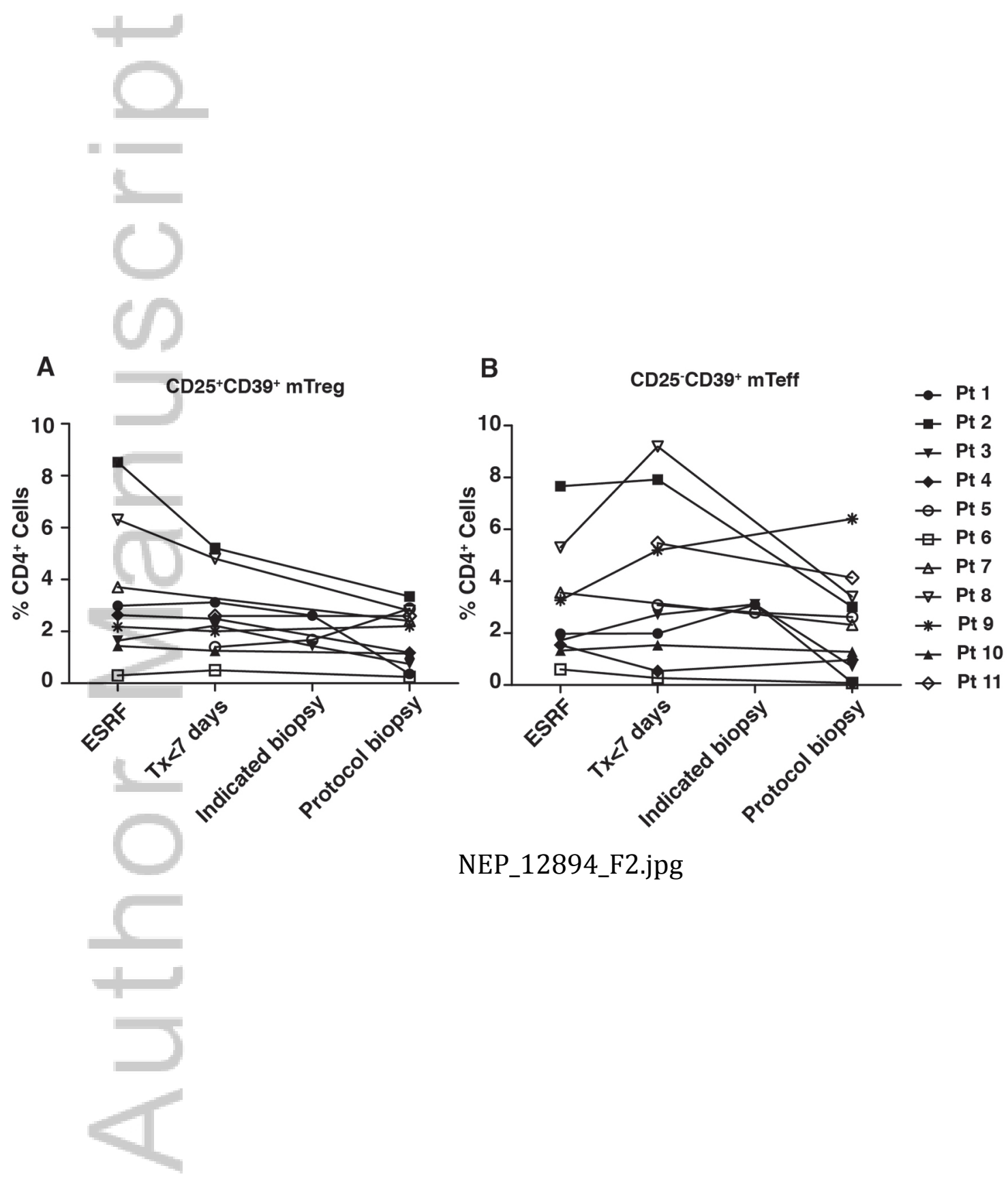

This article is protected by copyright. All rights reserved. 


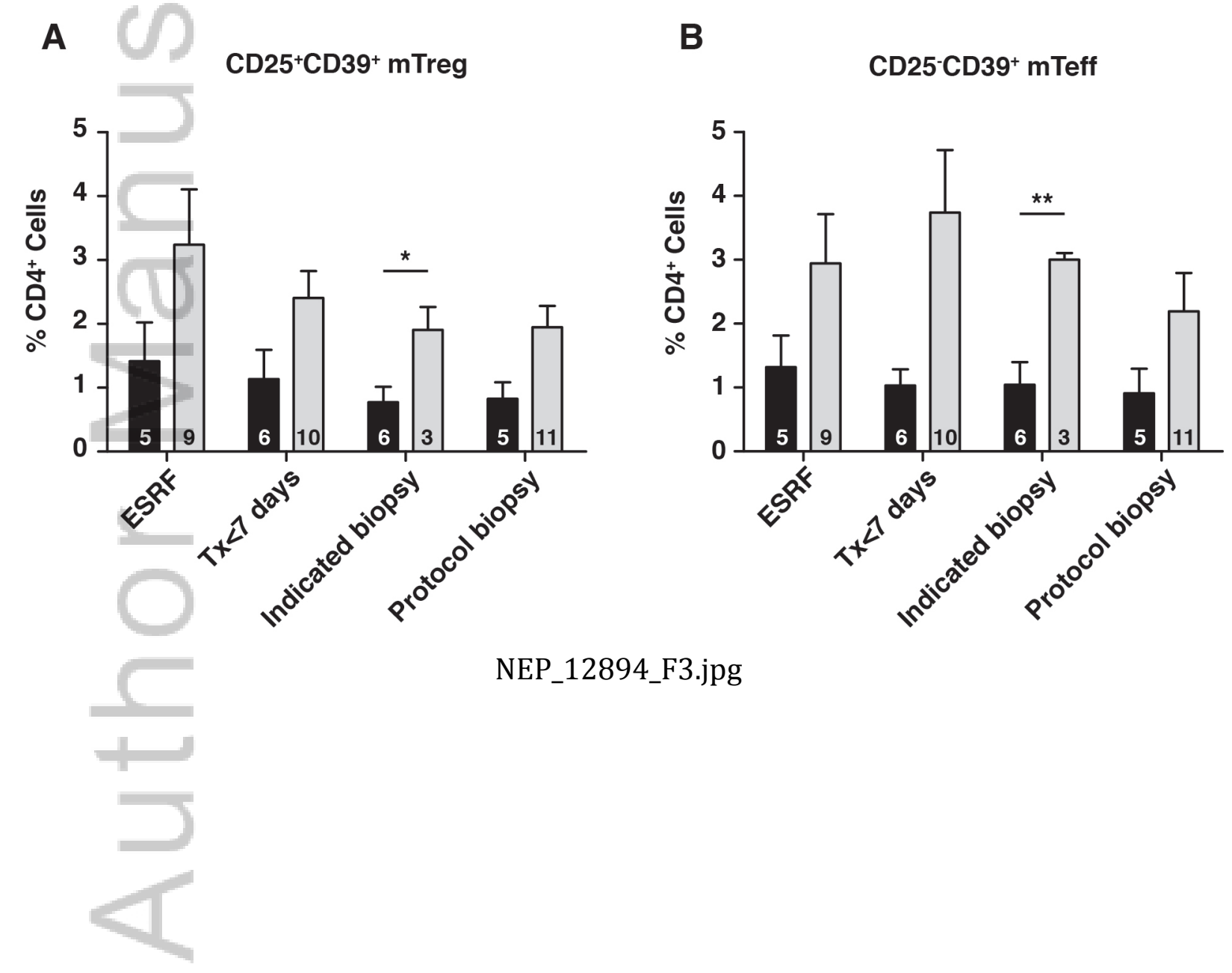

This article is protected by copyright. All rights reserved. 


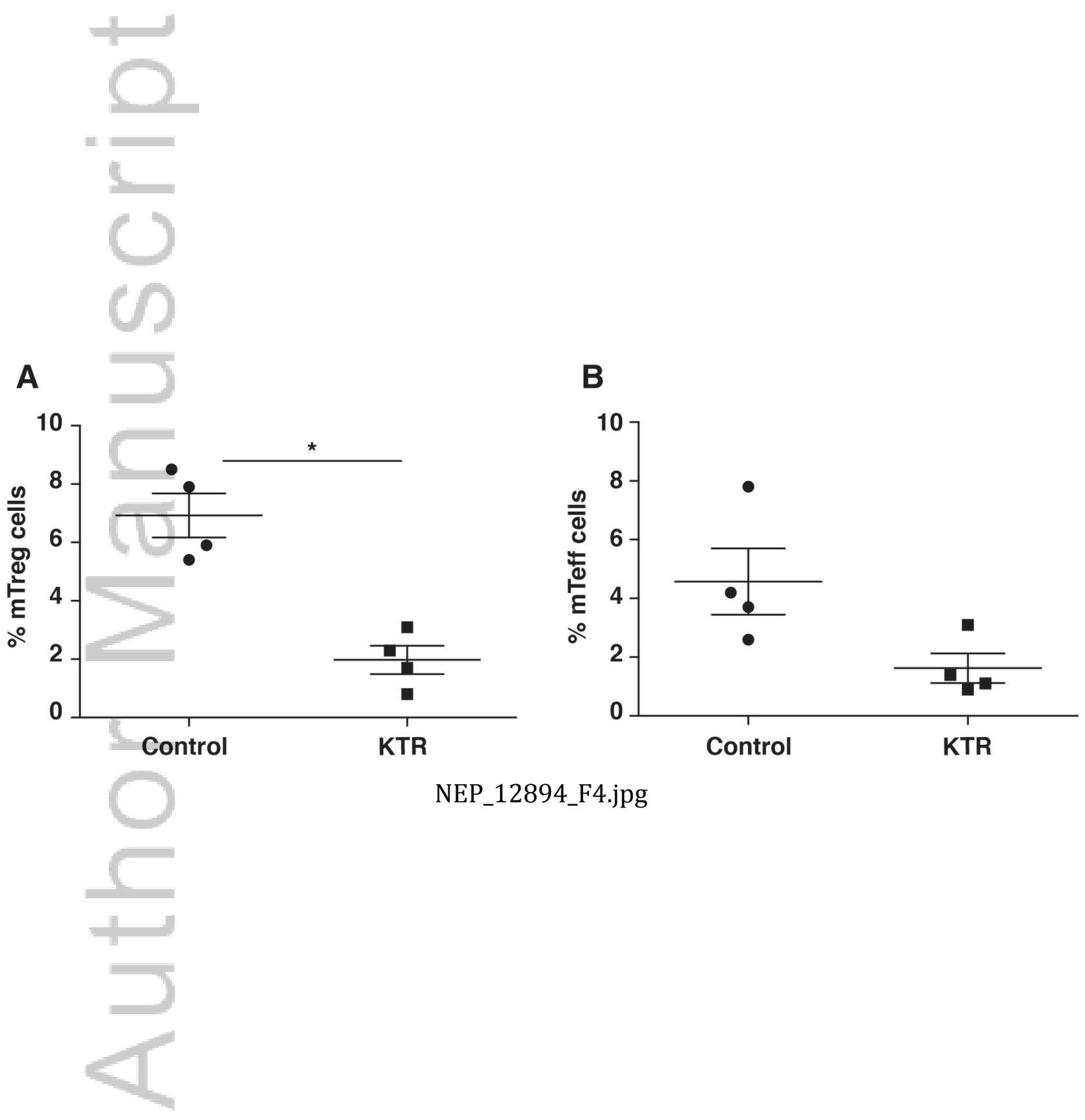

This article is protected by copyright. All rights reserved. 

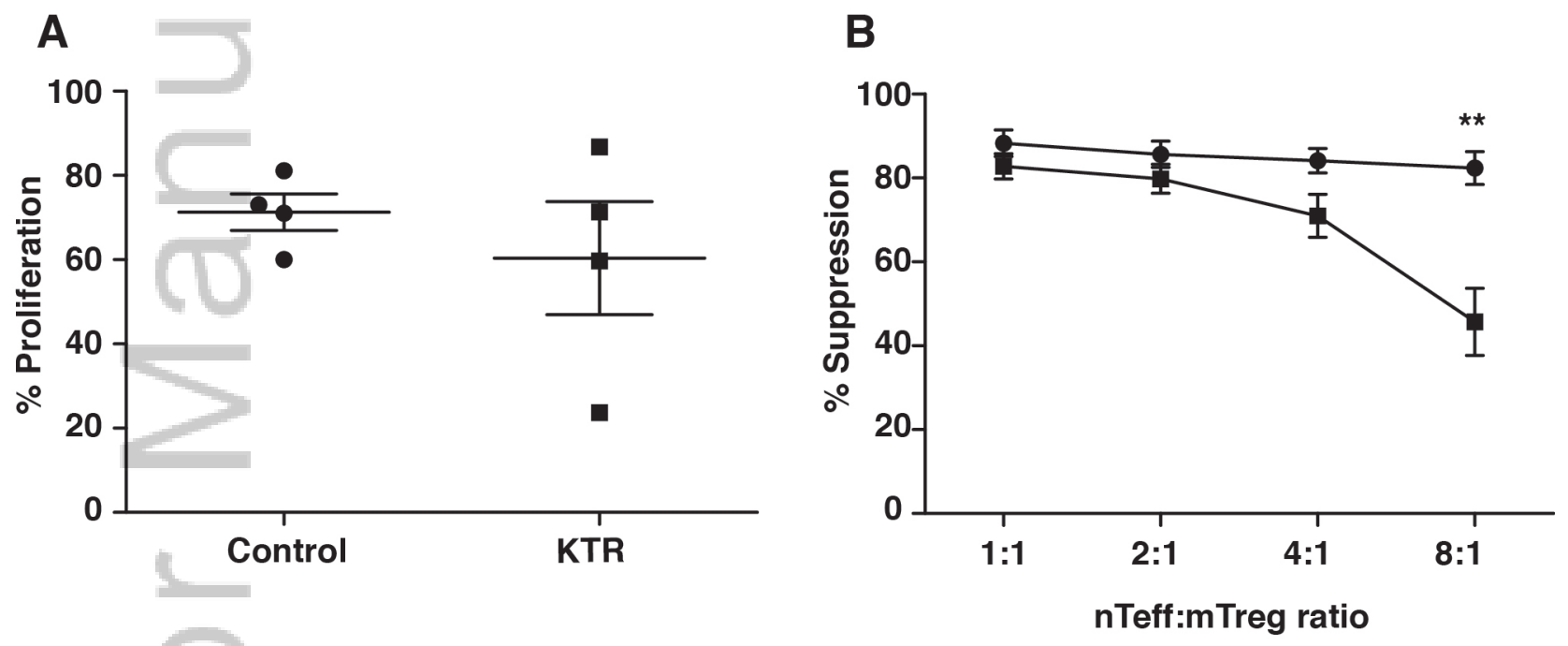

NEP_12894_F5.jpg

This article is protected by copyright. All rights reserved. 


\section{University Library}

\section{- M I I N E R VA \\ A gateway to Melbourne's research publications}

Minerva Access is the Institutional Repository of The University of Melbourne

Author/s:

McRae, JL;Chia, JSJ;Pommey, SA;Dwyer, KM

Title:

Evaluation of CD4(+)CD25(+/-)CD39(+) T-cell populations in peripheral blood of patients following kidney transplantation and during acute allograft rejection

Date:

2017-07-01

Citation:

McRae, J. L., Chia, J. S. J., Pommey, S. A. \& Dwyer, K. M. (2017). Evaluation of CD4(+)CD25(+/-)CD39(+) T-cell populations in peripheral blood of patients following kidney transplantation and during acute allograft rejection. NEPHROLOGY, 22 (7), pp.505-512. https://doi.org/10.1111/nep.12894.

Persistent Link:

http://hdl.handle.net/11343/293037 